\title{
Fen Bilgisi Öğretmen Adaylarının Sıfır Atık Yaklaşımına Yönelik Farkındalıkları
}

\author{
Awareness of Preservice Science Teachers on Zero Waste Approach \\ Gonca HARMAN*, Nisa YENIKALAYCI** \\ • Geliş Tarihi: 10.07.2019 • Kabul Tarihi: 29.12.2019 • Çevrimiçi Yayın Tarihi: 10.02.2020
}

\section{$\ddot{O} \mathbf{z}$}

$\mathrm{Bu}$ araştırmada Fen Bilgisi öğretmen adaylarının sıfır atık yaklaşımına yönelik farkındalıklarının incelenmesi amaçlanmıştır. Genel tarama modeli ile gerçekleştirilen araştırma 2018-2019 bahar yarıyılında bir devlet üniversitesinde Fen Bilgisi Eğitimi Anabilim Dalı dördüncü sınıfta öğrenim gören 29 öğretmen adayının gönüllü katılımı ile gerçekleştirilmiştir. Veri toplama aracı olarak araştırmacılar tarafından hazırlanan farkındalık formu kullanılmıştır. Bu formda yer alan üç açık uçlu soru ile öğretmen adaylarından sıfır atık kavramının tanımını, sıfır atık yaklaşımının uygulanmasının gerekliliğini ve sıfır atık yaklaşımının amaçlarını yazmaları; bununla birlikte sıfır atık yaklaşımına uygun bir bez çanta tasarlamaları ve tasarımlarını yapacakları çizimler ile ortaya koymaları istenmiştir. Elde edilen veriler içerik analizi ile çözümlenmiştir. Araştırma sonucunda öğretmen adaylarının sıfır atık yaklaşımına yönelik farkındalıklarının yeterli olmadığı saptanmıştır. Öğretmen adaylarının sıfır atık yaklaşımına ilişkin ifadelerinin atık yönetimi ve geri kazanım, çevresel etkiler, tasarruf, ekonomi ve toplumu bilinçlendirme temelinde yapılandığı anlaşılmıştır.

Anahtar sözcükler: farkındalık, sıfır atık, fen bilgisi öğretmen adayı

Atıf:

Harman, G., \& Yenikalaycı, N. (2020). Fen bilgisi öğretmen adaylarının sıfır atık yaklaşımına yönelik farkındalıkları. Pamukkale Üniversitesi Eğitim Fakültesi Dergisi, 50, 138-161.doi: 10.9779/pauefd.589781

Dr. Öğr. Üyesi, Karamanoğlu Mehmetbey Üniversitesi, Eğitim Fakültesi, Fen Bilgisi Eğitimi, drgoncaharman@hotmail.com, ORCID ID: 0000-0002-9717-1150

*** Arş. Gör., Ondokuz Mayıs Üniversitesi, Eğitim Fakültesi, Fen Bilgisi Eğitimi, nisa.yenikalayci@omu.edu.tr, ORCID ID: 0000-0002-5676-1488 


\begin{abstract}
The aim of this study was to determine the awareness of preservice science teachers on zero waste approach. The research that carried out with the general screening model was carried out with the voluntary participation of 29 preservice science teachers in the fourth year of a public university in the spring semester of 2018-2019. A form of awareness was prepared by the researchers as data collection tool. Preservice teachers were asked to write the definition of zero waste concept, the necessity of applying zero waste approach and the objectives of zero waste approach with three open-ended questions in this form; also, they were asked to design a cloth bag suitable for zero waste approach and to present their designs with drawings. The data were analyzed by content analysis. As a result of the research, it was determined that preservice science teachers' awareness on zero waste approach wasn't sufficient. It was understood that preservice science teachers' statements on zero waste approach were structured on the basis of waste management and recovery, environmental impacts, savings, economy and society awareness.
\end{abstract}

Key words: awareness, zero waste, preservice science teacher

\title{
Cited:
}

Harman, G., \& Yenikalayc1, N. (2020). Awareness of preservice science teachers on zero waste approach. Pamukkale Üniversitesi Eğitim Fakültesi Dergisi, 50, 138-161.doi: 10.9779/pauefd.589781 


\section{Giriş}

Atık oluşturmak doğal kaynakları tüketmek, enerji ve su kullanmak, toprağa baskı yapmak, çevreyi kirletmek ve atık yönetimi için ek maliyetler oluşturmak gibi anlamları içermektedir (Nizar, Munir, Munawar \& Irvan, 2018; Song, Li \& Zeng, 2015; Uz-Zaman \& Lehmann, 2013). $\mathrm{Bu}$ olumsuz sonuçların önüne geçmek için malzemenin atık olarak kabul edilmemesi ve olabildiğince faydalı ürünlere dönüştürülmesi gerektiğini savunan bir anlayışa geçiş zorunludur. $\mathrm{Bu}$ anlayış sıfır atık olarak ifade edilmektedir (Nizar, Munir, Munawar \& Irvan, 2018). Sıfır atık, atığı bir problem olarak görmek yerine fayda sağlayacak iyi bir potansiyel kaynak olarak kabul etmektedir (Elgizawy, El-Haggar \& Nassar, 2016). Bu kabul üzerinde küresel 1sınma ve kaynakların tükenmesi sonucunda daha öncelerde endüstriler ve toplumlar için bir yük olarak görülen atıkların toplanması, ayrılması, yönetilmesi ve geri kazanılması için çözümler gerektiren değerli bir kaynak olarak tanımlanmaya başlanması etkilidir (Lehmann, 2011).

Sıfır atık yaklaşımı çevre bilincinin temelini oluşturan "Reduction (azaltma), Reuse (yeniden kullanım) ve Recycle (geri dönüşüm)" olmak üzere 3R kuralını içerir (Song, Li \& Zeng, 2015). 3R kuralı çevremizi korumak ve ekonomimizi geliştirmek için harika bir yoldur. Ayrıca sürdürülebilir bir yaşam için bize yardımcı olabilir. 3R kuralı sorumlu ve sürdürülebilir çevresel davranışları teşvik eder. İnsanların tüketim ve atık üretimi hakkında düşünmelerini, oluşturdukları atıkları ve çevre üzerindeki etkilerini azaltmak için yaşam tarzları ile ilgili kararlar almalarını sağlayabilir. Bu nedenle tüm toplum atık azaltma, yeniden kullanım ve geri dönüşümün yararları hakkında eğitilmelidir (Samiha, 2013). Öyle ki, sıfır atığın temel hedefi, atılan malzemeleri tekrar kullanmaları için insanlara yaşam tarzlarını ve uygulamalarını değiştirmeye yönelik nasıl bir rehberlik yapılacağına odaklanmaktır (Song, Li \& Zeng, 2015).

Azaltma: Azaltma veya en aza indirme atık üretim miktarını azaltmaya yönelik tüm eylemleri içerir. Atık azaltma sürdürülebilir kalkınmanın sağlanması için en önemli stratejilerden biridir. Atık önlemenin hammadde kullanımında tasarruf sağlama ve atık üretiminde düşüşe neden olma gibi ekonomik ve çevresel faydaları vardır. Atık miktarının azaltılması değerli kaynakları ve çevreyi korumaya, toplama ve arıtma işlemlerinde azalmaya, malzeme, maliyet ve enerji tasarrufuna önemli katkılar sağlar (URL).

Atık önleme genellikle atık üretmeyerek azaltma anlamına gelir. Aynı zamanda dayanıklı, uzun ömürlü malları satın almayı ve mümkün olduğunca toksik maddeler içermeyen ürün ve ambalajları tercih etmeyi içerir. $\mathrm{Bu}$ durum tek kullanımlık ürünlerden tekrar kullanılabilir ürünlere geçiş yapmak kadar basit ya da daha az hammadde kullanmak veya daha uzun süre dayanan bir ürünü yeniden tasarlamak kadar karmaşık olabilir. Atık önleme atık oluşumunu önlediği için en çok tercih edilen atık yönetimi etkinliğidir (Song, Li \& Zeng, 2015).

Yeniden kullanım: Azaltmayı izleyen strateji yeniden kullanımdır. Yeniden kullanım stratejisi tüm azaltma olanakları tükendiğinde uygulanmaktadır. Yeniden kullanım atılan bir öğeyi veya malzemeyi tekrar kullanma işlemidir. Yeniden kullanım herhangi bir fiziksel veya kimyasal değişiklik olmadan orijinal haliyle yapılmaktadır. Yeniden kullanım programları iyi düşünüldüğü sürece sosyal, ekonomik ve çevresel faydalar sunmakta olup sürdürülebilir kalkınmaya katkıda bulunur ve sıfır atık hedeflerine ulaşılmasına yardımcı olur (URL). Yeniden kullanım geri dönüşüme göre daha az enerji gerektirir; ancak tüketicinin "yeni olma" arzusu gibi istekleri yeniden kullanımın önünde bir engel oluşturabilir (Song, Li \& Zeng, 2015). Bu 
engele rağmen eşyaları mümkün olduğunca tekrar kullanmalıyız ve ikinci el ürünlerin tüketimini teşvik etmeliyiz (Samiha, 2013).

Geri dönüşüm: Azaltma ve yeniden kullanımın uygulanamaması durumunda bir sonraki uygun seçenek geri dönüşümdür. Atılan malzemelerin geri dönüşümü, malzemelerin geri kazanılıp yeni ürünlere dönüştürülebilmesi için işlendiği süreçtir. Geri dönüşüm seçeneğinde geri kazanılan ürün veya malzeme değerli bileşenlerin veya materyallerin kurtarılması için fiziksel veya kimyasal olarak işlenebilir (URL). Geri dönüşümde doğal kaynak ve hammadde (Nayak, 2016) ile potansiyel olarak yararlı malzemelerin israfını önlemek, hammadde tüketimini, enerji kullanımını, hava kirliliğini (yakma) ve su kirliliğini (atık depolama) (Song, Li \& Zeng, 2015), sera gazı emisyonlarını azaltmak, biyolojik çeşitlilik ve habitatların korunmasını sağlamak (Nayak, 2016), malzeme ve enerjiyi korumak, depolama alanlarına giden malzemelerin miktarını azaltmak, ekonomiye katkıda bulunmak, iş üretmek ve çevreyi korumak (URL) için atık malzemeler yeni ürünlere dönüştürülür (Song, Li \& Zeng, 2015). Tüm dünyada kullanılan en yaygın stratejilerden biri olan geri dönüşüm sürdürülebilir atık yönetimine katkıda bulunur (URL).

Atık yönetimini temel alan sıfır atık bir toplumun stratejik vizyonudur. Bu vizyon sistemdeki hammaddelerin yakılması ya da çöplüklerde sonlanması yerine geri dönüştürülmesi gerektiğini savunur. Ayrıca düşünce biçimimizde ve alışkanlık halini almış davranışlarımızda değişiklik gerektirir. Doğal kaynakların daha akıllıca nasıl yönetileceği ve toplam atık hacmi ile tehlikelerinin nasıl azaltılacağı konusunda düşünmemizi sağlar (Monok, Stoykova, Bendere, Tömöri \& Popelkova, 2006). Sıfır atık çöp yakma tesislerine, büyük depolama alanlarına ve tüketim toplumuna "hayır" derken sürdürülebilir bir topluma “evet" der (Connent, 2007).

Sıfır atık temiz üretim, üretici sorumluluğu, atıkların kaynağında ayrılması (Snow, 2002), atık miktarını önleme ve azaltma (Oktaviani \& Supriatna, 2018), yeniden kullanım ve geri dönüşüm ile birlikte ürünün tüm yaşam döngüsünü dikkate alan tasarımlara önem verir. $\mathrm{Bu}$ tasarımlarda daha az malzeme ile geri dönüştürülebilen malzeme kullanımı, daha uzun ürün ömrü, tamir kabiliyeti ve kullanım ömrünün sonunda kolay ayrışabilen ürünler için çaba gösterilir (Nayak, 2016).

Sıfır atık stratejisi, işlenmemiş malzemelerin çıkarılması ve rafine edilmesi ihtiyacını, halk sağlığı risklerini, çöplüklerle ilgili sera gazı emisyonlarını ve üretimde tüketilen enerjiyi azaltmaya yardımcı olmaktadır (Elgizawy, El-Haggar \& Nassar, 2016). Her türlü atığı tanımlamak, önlemek ve azaltmak için yenilikçi yollar ortaya çıkaran sıfır atık çevreyi koruyarak, maliyetleri azaltarak, atıkların yönetimi ve işlenmesinde ek işler üreterek sürdürülebilirliği güçlü bir şekilde desteklemektedir (Nayak, 2016; Song, Li \& Zeng, 2015). Toplama noktaları, tamirhaneler, servis işyerleri, kullanılmış ikinci el eşya dükkânları ve kitapçılar gibi hizmetlerin gelişimini ve her türlü işe alım hizmetini desteklemektedir (Monok vd., 2006). Enerji, su ve malzeme kullanımını azaltarak, yeniden kullanarak ve geri dönüştürerek atıkları en aza indirmek için sayısız firsat sunmaktadır (French, Hamman, Katz \& Kozaki, 2010).

Sıfır atığa yönelik gerçekleştirilen çalışmaların etkililiği için (i) atıkları bütünsel olarak yönetmek, (ii) ürün ve hizmetlerin akıllı planlama faaliyetlerini ele alan rehberlik / politikalar geliştirmek, (iii) vatandaşlarla iletişim kurmak ve onları eğitmek, (iv) yeşil tedarik zincirleri geliştirmek, (v) hammadde seçiminde malzeme verimliliğine odaklanmak, (vi) uzun ömürlü 
ürünleri planlamak ve eklemek, (vii) düzenli depolama alanlarının yeterli yönetimi için teknolojilere yatırım yapmak gereklidir (Pietzsch, Duarte-Ribeiro \& Medeiros, 2017). Eğer çalışmalar açık ve uyumlu bir şekilde yapılabilirse sıfır atıktan sosyal, ekonomik ve çevresel açıdan büyük kazançlar elde edilebilir (Song, Li \& Zeng, 2015).

Sürdürülebilir ve daha verimli bir geleceğe imkân sağlayan (Nayak, 2016) sıfır atık hareketi sürdürülebilir tarım ve enerji, yeşil mimari, ekonomik ve toplumsal kalkınma ve iş imkânları oluşturma olmak üzere sürdürülebilir bir geleceğin çeşitli talepleriyle ilişki halindedir (Connent, 2007). Küresel iklim değişikliği ve insan yaşamındaki çeşitli etkileri toplumu sürdürülebilirliğe itmektedir. Sınırlı küresel kaynakların tükenmesi bireyleri kaynak ve ürün yönetimini düşünmeye zorlamaktadır. Bu nedenle "sıfır atık" yönetimi atık ve kaynakları sürdürülebilir bir perspektiften önleme ve yönetme bağlamında bütünsel bir bakış açısına sahiptir (Song, Li \& Zeng, 2015).

Çoğu insan azaltma, yeniden kullanım ve geri dönüşüm hakkında bilgi sahibidir ancak sürdürülebilirliğin anahtarı olan dördüncü unsur sorumluluktur. Sıfır atık yaklaşımının sürdürülebilir bir nitelik kazanması için her insanın soruna dâhil olması gereklidir (Connent, 2007). Bu değerli dünyayı korumanın yanı sıra onu daha yeşil, daha az toksik ve daha yaşanabilir hale getirmede azaltma, yeniden kullanım ve geri dönüşümde bu gezegende yaşayan her bireyin bir rolü vardır (Samiha, 2013). Herkesin ulusal ve küresel kirlenmede payı olduğu ve bu durumun yalnızca hükümetler tarafından çözülemeyeceği, bireysel çabaların önemli olduğu aşikârdır (Nayak, 2016). Bununla birlikte atıkları azaltmak, yeniden kullanmak ve geri dönüştürmek için tüm insanların birlikte harekete geçmeleri gerekir (Song, Li \& Zeng, 2015). Bireylerin ortak hareketi katı atık oluşumunu, su ve enerji kullanımını azaltacak ve dünyadaki kirliliğin azalmasına neden olacaktır (Nayak, 2016). Aksi takdirde bireyler atık oluşturdukları her gün gezegende sürdürülebilir olmayan bir yaşam biçiminin parçası olurlar. Bunu önlemek için bireyler atık oluşturmama, atıkları ayırma, gereksiz ürünlerden ve ambalajlardan kaçınma konularında hassas olmalıdırlar. Bu doğrultuda atıklardan kurtulma konusunda aşırı tüketimle mücadele ederek ihtiyacımız olmayan şeyleri satın almamalıyı. Benzer şekilde endüstriler de tekrar kullanılmayan şeyler üretmemelidir. Bu bağlamda sıfır atığın sektöre verdiği "Ĕger onu tekrar kullanamayacaksak, geri dönüştüremeyeceksek veya kompost yapamayacaksak, onu üretmemelisiniz!" mesajı ile bireylere verdiği "Eğer onu tekrar kullanamayacaksak, geri dönüştüremeyeceksek veya kompost yapamayacaksak, onu satın almamalıyı!!" mesajını (Connent, 2007) dikkate almalıyı. Bizlere verilen bu mesajlar doğrultusunda toplumumuzdaki bireyleri eğitim sistemimiz içerisinde atıklar konusunda ne kadar farkındalık sahibi olarak yetiştirdiğimizi anlamak için mevcut fen bilimleri dersi öğretim programı incelenmiştir. Öğretim programı kapsamında üçüncü sınıfta Elektrikli Araçlar ünitesinde öğrencilerin pil atıklarının çevreye vereceği zararları ve bu konuda yapılması gerekenleri tartışmaları; Canlılar Dünyasına Yolculuk ünitesinde tasarruf bilinci kazanmaları; dördüncü sınıfta İnsan ve Çevre ünitesinde kaynakların tasarruflu kullanımına yönelik bilgi ve becerileri kazanmaları, yeniden kullanımın ve geri dönüşümün önemini kavramaları; yedinci sınıfta Saf Madde ve Karışımlar ünitesinde ögrencilerin evsel katı ve sıv1 atıkların kontrol edilmesi, geri dönüşüm ve yeniden kullanımın önemini kavramaları; evsel atıklarda geri dönüştürülebilen ve dönüştürülemeyen maddeleri ayırt etmeleri, evsel katı ve sıvı atıkların geri dönüşümüne ilişkin projeler tasarlamaları, geri dönüşümü kaynakların etkili kullanımı açısından sorgulamaları, geri dönüşüm tesislerinin ekonomiye katkısını vurgulamaları, yakın çevrelerinde atık kontrolüne 
özen göstermeleri, atık kontrolü ile ilgili kamu ve sivil toplum kuruluşlarının çalışmalarına değinmeleri, yeniden kullanılabilecek eşyalarını ihtiyacı olanlara ulaştırmaya yönelik projeler geliştirmeleri; sekizinci sınıfta Enerji Dönüşümleri ve Çevre Bilimi ünitesinde öğrencilerin kaynakların kullanımında tasarruflu davranmaya özen göstermeleri ve buna yönelik projeler tasarlamaları, geri dönüşüm için katı atıkların ayrıştırılmasının önemini açıklamaları, geri dönüşümün ülke ekonomisine katkısına ilişkin araştırma verilerini kullanarak çözüm önerileri sunmaları; kaynakların tasarruflu kullanılmaması durumunda gelecekte karşılaşılabilecek problemleri belirterek çözümler önermeleri beklenmektedir (Millî Eğitim Bakanlığ1 [MEB], 2018). Tüm bunlar göz önünde bulundurulduğunda fen bilimleri dersi öğretim programında geri dönüşüm ve yeniden kullanım olmak üzere atıkların geri kazanımına yönelik hedeflere yer verildiği söylenebilir. Bireylerin rolüne yönelik farkındalık kazandırma, bilinçlendirme ve bilgilendirme bağlamında şüphesiz en önemli etkiyi eğitim faaliyetleri gösterecektir. Bu nedenle eğitime kılavuzluk eden öğretim programlarında atık yönetimi, geri dönüşüm, yeniden kullanım, geri kazanım ve sıfır atık konularına yer verilmesinin önemli olduğu düşünülmektedir. Öğretim programının uygulayıcıları olan öğretmenlerin ifade edilen hedeflere ulaşılmasında aktif rol alacakları düşünüldüğünde atık yönetimi, geri dönüşüm, yeniden kullanım, geri kazanım konularında ve bu konuları kapsayan sıfır atık yaklaşımında farkındalık sahibi bireyler olmaları gereklidir. Öyle ki, sıfir atık programlarının önündeki engelleyici faktör bireylerin çevrelerini koruma konusundaki farkındalık eksikliğidir (Choiriyah, 2017). Bu bağlamda farkındalık sahibi bireylerin yetiştirilmesi engellerin kaldırılması açısından son derece önemlidir.

Eğitim faaliyetlerinden yüksek düzeyde verim alınabilmesinde bireylerin mevcut durumunun tespit edilmesinin etkili olacağı düşünülmektedir. Bu düşünceyi destekler nitelikte alan yazında farklı eğitim kademelerindeki bireylerin atık yönetimi ile ilgili olarak bilgi, farkındalık, görüş, algı, bilişsel yapı ve zihinsel modellerini inceleyen araştırmalar bulunmaktadır. Bu araştırmalarda okul öncesi dönem çocuklarının (Can-Yaşar, İnal, Kaya ve Uyanık, 2012), ilköğretim 3., 4. ve 5. sınıf öğrencilerinin (Gönüllü, Doğan ve Çelik, 2015), ortaokul öğrencilerinin (Çimen ve Yılmaz, 2012), yetişkinlerin (Gürer ve Sakız, 2018) çoğunluğunun geri dönüşüm kavramıyla ilgili bilgi sahibi olduğu saptanmıştır. Olumlu sonuçların aksine fizik, kimya ve biyoloji öğretmen adaylarının atık yönetimi bağlamında çevreye karşı bilgi düzeylerinin yeterli olmadığ 1 (Demircioğlu, Demircioğlu ve Yadigaroğlu, 2015); 3. sınıfta öğrenim gören Fen Bilgisi öğretmen adaylarının ise pillerin geri dönüşüm süreci ile ilgili eksik ya da yanlış bilgilere sahip oldukları (Aksan, Harman ve Çelikler, 2015); fizik, kimya ve biyoloji öğretmen adaylarının atık yönetimi konusunda çevreye karşı bilgi düzeylerinin yeterli olmadığı (Demircioğlu, Demircioğlu ve Yadigaroğlu, 2015) ortaya koyulmuştur.

Üniversite öğrencilerinin çoğunun katı atık yönetimine yönelik farkındalıklarının tam olduğu (Paghasian, 2017), Fen Bilgisi öğretmen adaylarının tamamına yakınının geri dönüşümün anlamı, gerekliliği ve yapılış amacı ile ilgili farkındalıklarının yeterli olduğu, buna karşın geri dönüşüme uğrayabilecek atık türlerine yönelik farkındalıklarının düşük olduğu (Harman ve Çelikler, 2016) anlaşılmıştır. Başka bir araştırmada organik atıkların dışında kalan atıkların türlerine göre farklı geri dönüşüm kutularına atılması gerektiğini ifade eden Fen Bilgisi öğretmen adaylarının ambalaj üretiminde kullanılan malzemelerin tekrar değerlendirilebileceğinin farkında oldukları ortaya koyulmuştur (Harman ve Çelikler, 2018). 
Sürdürülebilirliğe ilişkin farkındalığın incelendiği bir diğer araştırmada atık yönetimi ile ilgili olarak 3. sınıfta öğrenim gören bazı Fen Bilgisi öğretmen adaylarının bahçeye ve sınıfa çoğunlukla kâğıt, plastik ve cam olmak üzere, metal ve atık piller için de geri dönüşüm kutuları çizdikleri, az sayıda öğretmen adayının bahçeye ve sınıfa tüm atıklar için genel bir geri dönüşüm kutusu, bazılarının ise atıklar için çöp kovası çizdikleri saptanmıştır (Harman, 2017). $\mathrm{Bu}$ sonuçların aksine başka bir araştırmada tüketicilerin ifade ettikleri çevre koruma davranışlarının çevre kirliliğine neden olabileceğinin farkında olmadıkları, geri dönüşüm hakkında kafa karışıklığı yaşadıkları; yeniden kullanım, yeniden imalat ve geri dönüşüm kavramlarını birbiri ile karıştırdıkları, geri dönüşüm sonucunda ortaya çıkan ürünlerin sağlık açısından zararlı olduğuna yönelik bir algıya sahip oldukları saptanmıştır (Özbakır-Umut, Topuz ve Nurtanış-Velioğlu, 2015).

Ortaokul 6. sınıf öğrencilerinin ambalaj atıklarının geri dönüşümüne yönelik görüşlerinin olumlu olduğu ve geri dönüşümün gerekli olduğunu düşündükleri (Develi vd., 2017), bu durumun aksine ilköğretim 8. sinıf öğrencilerinin çevre sorunlarına yönelik görüşlerinde sadece bir öğrencinin geri dönüşüm kutularının kullanılmasını gerekli gördüğg̈ (Yalçınkaya, 2013) ortaya koyulmuştur.

İlkokul 4. sınıf öğrencilerinin çevre sorunları ve çevre eğitimine yönelik algıları incelendiğinde öğrencilerin Dünya'da ve Türkiye'de en fazla yaşanan çevre sorununun çöp atıkları olduğunu ve bu sorunun geri dönüşüm uygulamaları ile çözülebileceğini ifade ettikleri görülmüştür (Ertürk, 2017). Benzer şekilde ilköğretim 8. sınıf öğrencileri için çevre sorunları genel olarak çöp odaklı olmasına karşın sadece bir öğrencinin geri dönüşümün olduğu bir çevrede yaşamak istediğini ifade etmesi dikkat çekicidir (Yardımcı ve Bağc1-Kılıç, 2010).

8. sınıf öğrencilerinin geri dönüşüm ve tekrar kullanım kavramları hakkındaki bilişsel yapıları incelendiğinde geri dönüştürülen maddeler ile tekrar kullanılan maddeleri birbirinden ayırmada güçlük yaşadıkları (Atabek-Yiğit ve Ceylan, 2015); Fen Bilgisi Öğretmenliği 1. sınıfta öğrenim gören öğrencilerin geri dönüşüme yönelik davranışlarını etkileyecek zihinsel modellerinin sınırlı olduğu (Harman, Aksan ve Çelikler, 2015) saptanmıştır. Fen Bilgisi öğretmenliği 3. ve 4. sınıfta öğrenim gören öğretmen adayları (Aksan ve Çelikler, 2018) ile 3. sınıfta öğrenim gören Fen Bilgisi ögrencileri (Harman ve Çelikler, 2015) tarafından hazırlanan modellerde geri kazanım, geri dönüşüm ve yeniden kullanımın vurgulandığı, katı atık türlerinin kullanıldığ 1 ve atık maddenin farklı bir amaç için yeniden kullanımı mesajının verildiği görülmüştür.

Bilgi, farkındalık ve tutum ile bunların davranışta kendini göstermesine yönelik çalışmalar incelendiğinde ilköğretim 3., 4. ve 5. sınıf öğrencilerinin geri dönüşüm kavramına yönelik bilgilerinin (Gönüllü, Doğan ve Çelik, 2015), ortaokul öğrencilerinin atık yönetimine ilişkin tutumlarının (Yakob, Esa ve Yunus, 2012), geri dönüşüm kavramıyla ilgili bilgilerinin (Çimen ve Yılmaz, 2012) davranışta kendini gösterdiği; üniversite öğrencilerinin katı atık yönetimine ilişkin farkındalıklarının atık azaltma, yeniden kullanım ve geri dönüşüm davranışlarına da yansıdığı (Paghasian, 2017) ortaya koyulmuştur. Üniversite öğrencilerinin çevre konusunda sorumluluklarının bilincinde oldukları, bu bilinci davranışlarına yansıttıkları saptanmıştır. Öyle ki, öğrencilerin her zaman çevre ve diğer insanlar için daha az zararlı ve geri dönüştürülebilir olan ürünü tercih ettikleri, ev çöplerini ayırarak geri dönüşüme katkı sağlamaya çalıştıkları, mümkün olduğunca yeniden kullanılabilir kaplarda satılan ürünleri satın aldıkları 
belirlenmiştir. Çevreye saygı göstermeyen firmaların ürünlerini satın almamaya dikkat ettikleri ve çevrelerini de bu ürünleri satın almamaları için ikna etmeye çalıştıkları tespit edilmiştir (Türkmen, Sarıkaya ve Saygıl1, 2013). Ayrıca, katılımcı hanelerin atık yönetimine ilişkin davranışlarında yeniden kullanımın kendini gösterdiği anlaşılmıştır (Wegedie, 2018). Olumlu sonuçların aksine fizik, kimya ve biyoloji öğretmen adaylarının atık yönetimi konusunda çevreye karşı davranış düzeylerinin yeterli olmadığı ortaya koyulmuştur (Demircioğlu, Demircioğlu ve Yadigaroğlu, 2015).

Mevcut durumun tespitinin ardından, gerçekleştirilecek eğitim ve etkinliklerin etkililiğini ortaya koyan çalışmalar incelendiğinde; okul öncesi dönem çocukları ile gerçekleştirilen çevre konulu etkinliklerin öğrencileri geri dönüşüm konusunda bilgilendirdiği (Akbayrak ve Kuru-Turaşl1, 2017), atık kâğıtların değerlendirilmesi ve çevre bilincinin kazandırılmasına yönelik uygulamaların 5 yaşındaki çocukların geri dönüşüm konusunda bilgi sahibi olmalarını sağladığı (Onur, Çağlar ve Salman, 2016) saptanmıştır. İlkokul öğrencileri ile yapılan çalışmalarda atık konulu eğitimlerin ilkokul öğrencilerine bilgi ve bilinç kazandırdığı, bu kazanımların davranışa dönüştüğü, öğrencilerin ebeveynlerini de etkilediği (GrodzinskaJurczak, Bartosiewicz, Twardowska \& Ballantyne, 2003), çevre ile ilgili etkinliklerin 5. sınıf öğrencilerinin atık, doğal kaynakların korunması, tasarruf ve geri dönüşümü anlamalarında etkili olduğu ve farkındalık kazandırdığı (Gülhan ve Yurdatapan, 2014) ortaya koyulmuştur. Ortaokul öğrencileri ile yapılan çalışmalarda sosyal içerikli etkinliklerin ortaokul öğrencilerinin geri dönüşüm davranışlarını arttırdığı ve öğrencileri geri dönüşümü mümkün olan ürünleri kullanmaya güdülediği (Çimen ve Yılmaz, 2012); eko-okullarda gerçekleştirilen çevre faaliyetlerinin 8. sınıf öğrencilerinin hem kendilerinin hem de çevrelerinin bilinçlenmesine katkıda bulunmalarını sağladığı (Aktepe ve Girgin, 2009) tespit edilmiştir. Küçük yaş gruplarında görülen olumlu sonuçların yanı sıra büyük yaş gruplarında da benzer olumlu sonuçlar elde edilmiştir. Öyle ki, sıfır atık programının gençlere deneyim ve beceri kazandırdı davranışta etkisini gösterdiği (Choiriyah, 2017), mühendislik öğrencilerine geri dönüşebilir atıkların toplanması konusunda yapılan bilgilendirmenin atık toplamada verimi arttırdığ1 (Tufaner, 2019) ve SCAMPER tekniğinin 3. sınıf Fen Bilgisi öğrencilerinin katı atıkların toplanması ve değerlendirilmesine yönelik farkındalık oluşturmada etkili olduğu (Çelikler ve Harman, 2015) anlaşılmıştır.

Atığın istihdam olanakları sağlayan ve kullanılabilen bir kaynak olabilmesi için tüm bireyler bilgilendirilmeli, eğitilmeli ve katı atık yönetiminde karar alma sürecine dâhil edilmelidir (Tariq, Naveed, Irshad, Ahsan, Zafar, Shiraz \& Nauman, 2017). Bu bağlamda her tür eğitim kurumunun, özellikle yükseköğretim kurumlarının çevre koruma hareketinde önemli bir liderlik rolü üstlenmeleri gerekir. Yükseköğretim kurumları kapsamlı bir sürdürülebilirlik politikası geliştirmelidir. Bu politika fakülte, personel, öğrenci ve yerel yönetim temsilcileri arasında sürdürülebilir tedarik, yeşil satın alma, gıda yönetimi, atık azaltma ve geri dönüşüm programlarını kapsayacak şekilde bütünsel olmalıdır (Ebrahimi, 2015).

Öğretmen adaylarının gerek öğrenim gördükleri yükseköğretim kurumlarında gerekse ileride görev yapacakları okullarda öğrencileri ile birlikte hem öğretim programında yer alan hedeflere ulaşmaları hem de öğrencileri aracıllğı ile öğrenci velilerini de etkileyerek toplumsal boyutta atıkların geri kazanımına ve beraberinde sıfır atık yaklaşımına sağlayacakları katkı dikkate alındığında sıfır atık yaklaşımına yönelik farkındalık sahibi olup olmadıklarının ortaya 
koyulması gereklidir. Bu gereklilik temelinde gerçekleştirilen araştırmada Fen Bilgisi öğretmen adaylarının sıfır atık yaklaşımına yönelik farkındalıklarının incelenmesi amaçlanmıştır.

\section{Yöntem}

2018-2019 bahar yarıyılında bir devlet üniversitesinde Fen Bilgisi Eğitimi Anabilim Dalı dördüncü sınıfta öğrenim gören 29 öğretmen adayının gönüllü katılımı ile gerçekleştirilen araştırmada tarama deseni kullanılmıştır. Tarama deseninde bir evrenden alınan örneklem üzerinde yapılan çalışmalar aracılığıyla evrenin eğilim, tutum veya görüşleri saptanır. Araştırmacılar örneklemden elde ettikleri verilerden hareketle evren hakkında çıkarsamalarda bulunabilirler (Cresswell, 2017).

Veri toplama aracı olarak araştırmacılar tarafından hazırlanan farkındalık formu kullanılmıştır. Bu formda yer alan üç açık uçlu soru ile öğretmen adaylarından sıfır atık kavramının tanımını, sıfır atık yaklaşımının uygulanmasının gerekli olup olmadığını ve sıfır atık yaklaşımının amaçlarını yazmaları; bununla birlikte sıfır atık yaklaşımına uygun bir bez çanta tasarlamaları ve tasarımlarını yapacakları çizimler ile ortaya koymaları istenmiştir.

Araştırma kapsamında elde edilen veriler içerik analizi ile çözümlenmiştir. Verilerin analizinde her öğretmen adayı için veri kâğıtları numaralandırılmış, veri toplama aracında yer alan her soruya verilen cevaplar ayrı ayrı dosyalara ham hali ile kaydedilmiştir. Araştırma kapsamında öğretmen adaylarının verdikleri cevaplar ile yaptıkları çizimler içerik analizi ile çözümlenmiştir. İçerik analizi ile çözümlenen verilere ait frekans değerleri kullanılarak tablolar oluşturulmuş ve yorumlanmıştır. Veri analizinde geçerlik ve güvenirliğin sağlanması için elde edilen veriler fen eğitiminden iki araştırmacı tarafından ayrı ayrı analiz edilmiştir. Daha sonra araştırmacılar içerik analizi neticesinde ortaya çıkan kod ve kategorileri bir araya getirip karşılaştırarak bunları düzenlemişlerdir. Kodlayıcılar arasındaki güvenirlik [Görüş Birliği/(Görüş Ayrılığı + Görüş Birliği) x 100] formülü kullanılarak hesaplanmıştır (Miles ve Huberman, 1994). Bağımsız iki kodlayıcı arasındaki güvenirlik \% 92 bulunmuştur. Ayrıca ham veriler ile kodlar ve kategoriler teyit amacıyla alanında uzman bir kimya eğitimcisi tarafından incelenmiştir. Verilerin daha ayrıntılı bir biçimde betimlenmesi için öğretmen adaylarının cevaplarından doğrudan alıntılar ile yaptıkları çizimlerden örnekler öğretmen adayına verilen numara ile birlikte sunulmuştur.

\section{Bulgular}

Fen Bilgisi öğretmen adaylarının sıfır atığın tanımına ilişkin verdikleri cevaplar analiz edilerek Şekil 1'de verilmiştir. 


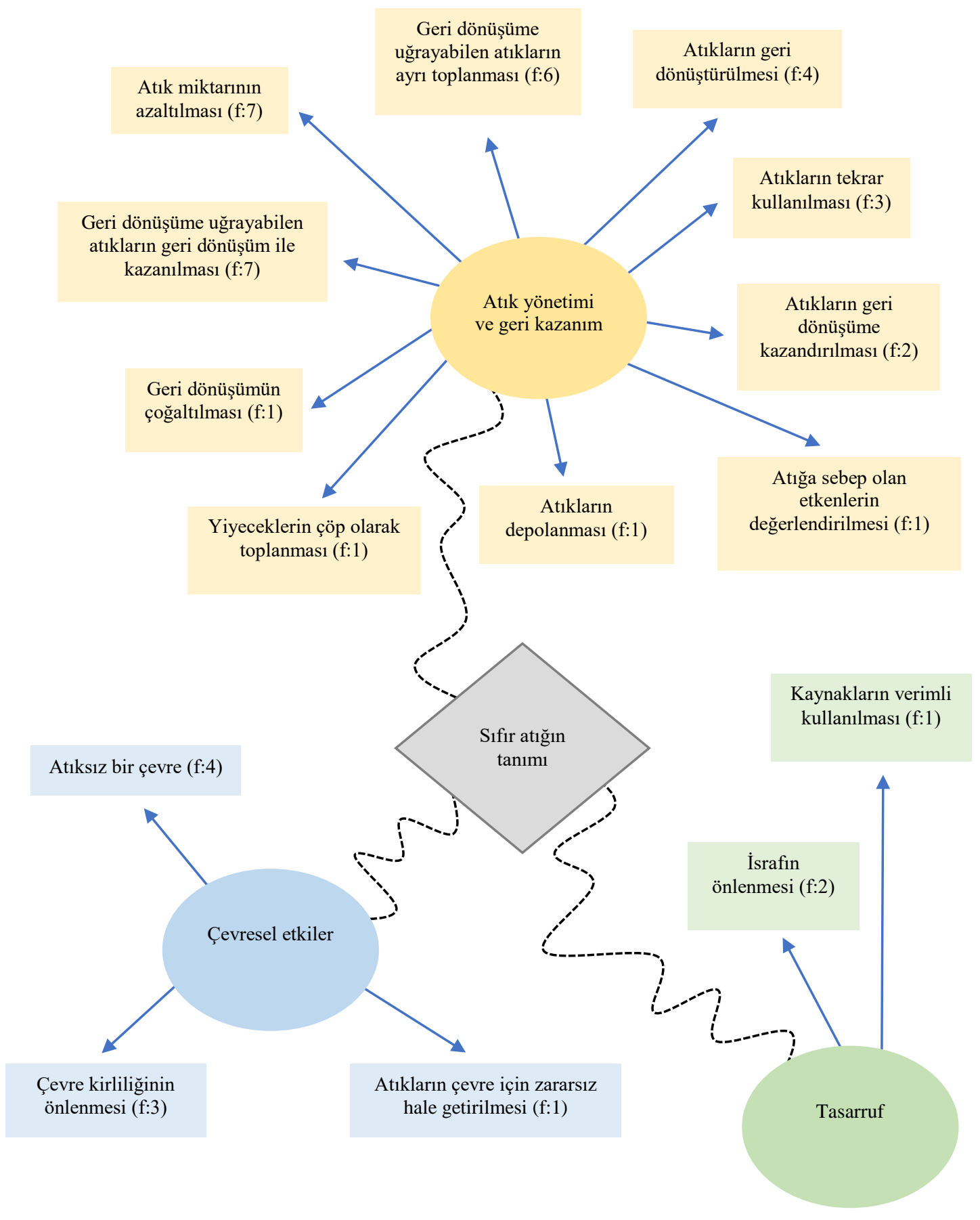

\section{Şekil 1. Sıfır atığın tanımı}

Şekil 1 incelendiğinde öğretmen adaylarının sıfır atık kavramını atık yönetimi ve geri kazanım kategorisinde daha çok geri dönüşüme uğrayabilen atıkların geri dönüşüm ile kazanılması (f:7), atık miktarının azaltılması (f:7), geri dönüşüme uğrayabilen atıkların ayrı toplanması (f:6) ve atıkların geri dönüştürülmesi (f:4); çevresel etkiler kategorisinde atıksız bir çevre (f:4); tasarruf kategorisinde ise israfin önlenmesi (f:2) olarak tanımladıkları görülmektedir. Öğretmen adaylarının çoğu yaptıkları tanımlarda geri dönüşüme uğrayabilecek 
atık madde türlerini belirtmezken 7 öğretmen adayı gıda atıkları ve diğer atıklar (f:1), ambalaj ve şişe (f:1), kâğıt, cam ve plastik (f:1), organik atık, plastik ve pil (f:1), organik atıklar hariç diğer atıklar (f:1), yiyecekler hariç plastik, kâğıt/karton, cam ve metal (f:1), cam, metal ve kâğıt (f:1) olmak üzere sınırlandırarak ifade etmişlerdir. Öğretmen adaylarının cevaplarından bazı örnekler aşağıda verilmiştir.

İsrafın önlenmesini, kaynakların daha verimli kullanılmasını, oluşan atık miktarının azaltılmasını kapsayan atık oluşumunu önlemek, çevre kirliliğini önlemek amacıyla yapılan bir hedeftir. $\left(\ddot{O}_{7}\right)$

Geri dönüşümü mümkün olan ürünlerin çöpe ya da doğaya atılmayarak, tekrar kazandırılmasıdır. (Ö̈)

Kullandığımız ürünlerin ambalajları, şişeleri vs. doğaya atılmadan geri dönüşüm aracılığıyla tekrar kullanılabilmesidir. $\left(\ddot{O}_{14}\right)$

Tüm atıkların kâğıt, cam, plastik vb. şekilde ayrılıp toplanmasına da yarar. Bu sayede tüm atıklar toplanır ve uygun şekilde geri dönüştürülür. (Ö $\left.{ }_{19}\right)$

Hayatımızda kullandığımız cam, metal, kâğıt gibi maddelerin çöp olarak atılması değil geri dönüştürülerek yeniden kullanılması yardımıyla çevrenin temiz kalması. $\left(\ddot{\mathrm{O}}_{27}\right)$

Fen Bilgisi öğretmen adaylarının sıfır atık yaklaşımının uygulanmasının gerekli olup olmadığına ilişkin verdikleri cevaplar analiz edilerek Şekil 2'de verilmiştir. 


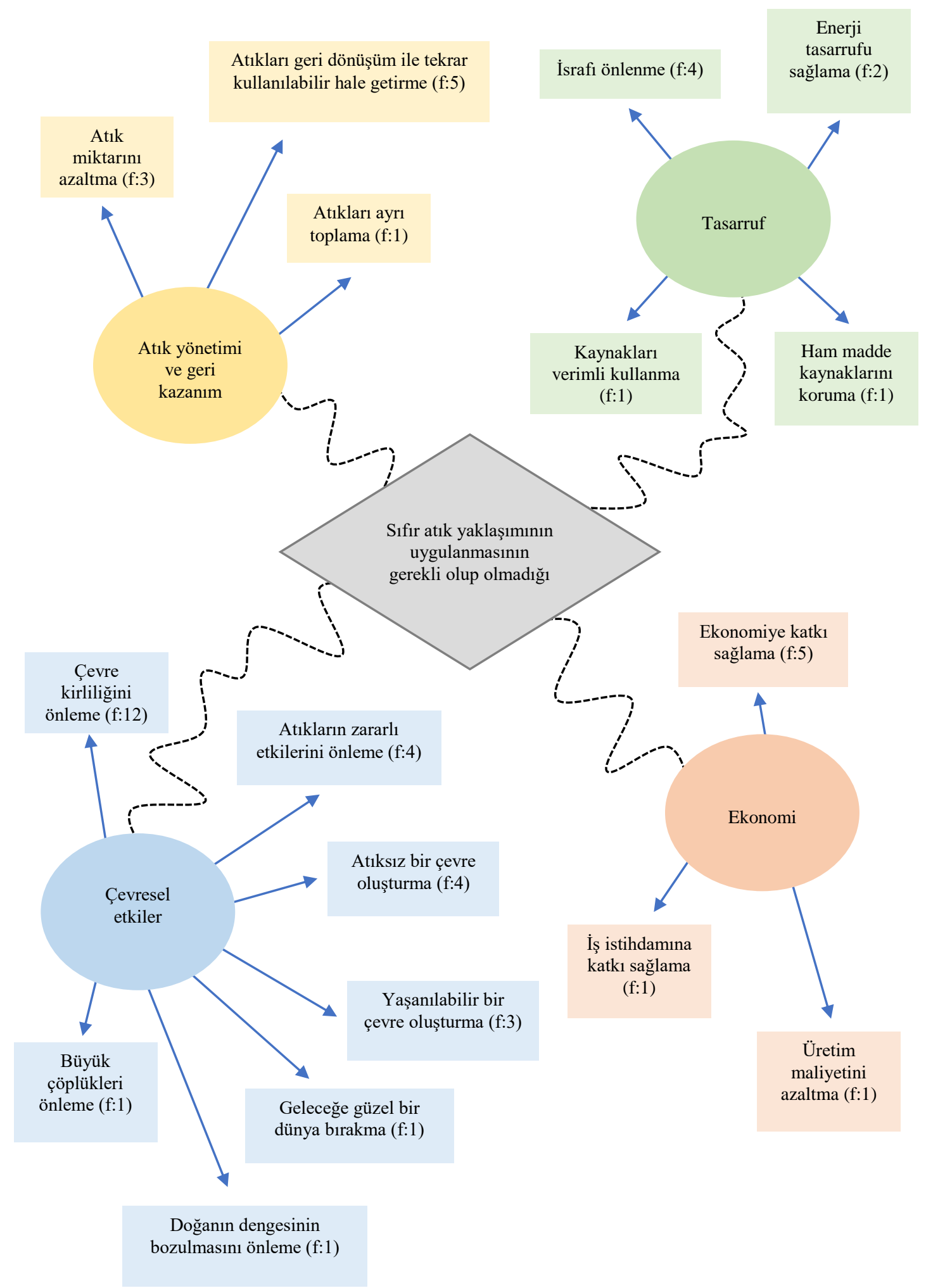

Şekil 2. Sıfır atık yaklaşımının uygulanmasının gerekli olup olmadığı 
Şekil 2 incelendiğinde 27 (\% 93,1) öğretmen adayının atık yönetimi ve geri kazanım, çevresel etkiler, tasarruf ve ekonomi olmak üzere 4 kategori açısından sıfır atık yaklaşımının uygulanmasının gerekli olduğunu ifade ettiği görülmektedir. Cevaplar atık yönetimi ve geri kazanım kategorisinde atıkları geri dönüşüm ile tekrar kullanılabilir hale getirme (f:5) ve atık miktarını azaltma (f:3); çevresel etkiler kategorisinde çevre kirliliğini önleme (f:12), atıkların zararlı etkilerini önleme (f:4) ve atıksız bir çevre oluşturma (f:4); tasarruf kategorisinde israfı önleme (f:4); ekonomi kategorisinde ekonomiye katkı sağlama (f:5) kodlarında yoğunlaşmıştır. Bunun yanı sıra $2(\%$ 6,9) öğretmen adayı ise kararsız olduklarını ifade etmişlerdir. Öğretmen adaylarının cevaplarından bazı örnekler aşağıda verilmiştir.

Kararsız: Gerekli olduğunu düşünüyorum ancak her zaman için değil. Çünkü hiç atık olmaması da normal bir şey değildir. Atıklardan çöplerden metan gazı oluşmakta ve enerji için kullanılabilmektedir. Kontrollü bir şekilde uygulanacaksa gereklidir. Bu ortamlarda yaşayan bazı canlılar için de atıklar gereklidir. ( $\ddot{O}_{6}$ )

Evet. Çünkü gün geçtikçe çevre kirliliği artıyor ve insanlar farkında olmadan israf yapıyorlar. Sıfır atık uygulanırsa hem çevre kirliliği önlenir hem de kaynakların daha verimli kullanılması sağlanır. $\left(\mathrm{O}_{7}\right)$

Evet. Çünkü dişarda gereksiz yere israf eden çok insan var. Çevreyi kirleten ve bunu önemsemeyen insanlar var. Bilinçli insanlar sayesinde diğer insanlar da bilgilendirilmeli, önemi anlatılmalı. $\left(\ddot{O}_{10}\right)$

Evet. Doğanın işleyişinin ve canlılığın yok olmaması için hiç atık olmaması uygulaması yapılabilir. Çevremizdeki geri dönüşümü yapılabilen ürünler toprak, deniz gibi yerlere atıldığında canlı yaşamı da zarar görür. Bu yüzden sıfır atık uygulaması yapılmalıdır. $\left(\ddot{O}_{14}\right)$

Kesinlikle düşünüyorum. Ülkemizde atık ve israf miktarı çok fazla. Oysa bu atıklar mümkün oldukça geri dönüştürülse hem ekonomiye katkı sağlar hem doğa daha az kirlenmiş olur hem de insanlara yeni iş kapıları açılmış olur. $\left(\ddot{\mathrm{O}}_{21}\right)$

Evet, bu sayede enerji tasarrufu sağlanır, maliyet azalır. Sıfırdan ürün üretmek daha maliyetlidir. Çevre kirliliği azalır (toprak, hava, su). Atıklar azaldığı için alandan tasarruf edilir. $\left(\ddot{\mathrm{O}}_{24}\right)$

Fen Bilgisi öğretmen adaylarının sıfır atık yaklaşımının amaçlarına ilişkin verdikleri cevaplar analiz edilerek Şekil 3’te verilmiştir.

Şekil 3 incelendiğinde öğretmen adaylarının sıfır atık yaklaşımının amaçlarını atık yönetimi ve geri kazanım, çevresel etkiler, tasarruf, ekonomiye katkı sağlamak ve toplumu bilinçlendirmek bağlamında ifade ettikleri görülmektedir. Cevapların atık yönetimi ve geri kazanım kategorisinde atık miktarını azaltmak (f:7), atıkları geri dönüşüm ile kazanmak (f:6); çevresel etkiler kategorisinde yaşanabilir bir çevre oluşturmak (f:22); tasarruf kategorisinde ham madde kaynaklarını verimli kullanmak (f:4), israfı önlemek (f:3) kodlarında; ekonomiye katkı sağlamak (f:7) ile toplumu bilinçlendirmek (f:5) kategorilerinde yoğunlaştığı görülmektedir. Öğretmen adaylarının cevaplarından bazı örnekler aşağıda verilmiştir. 


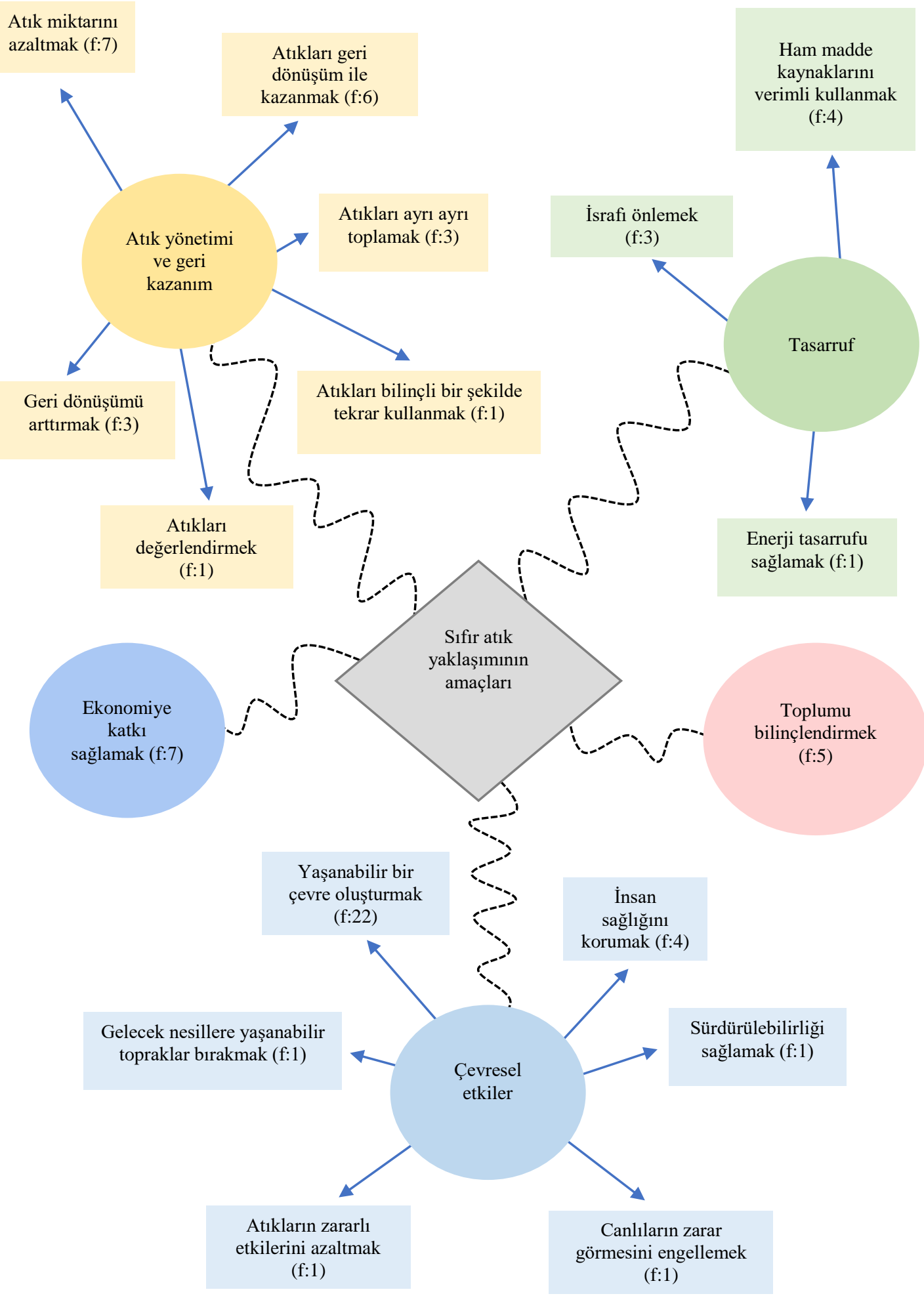

Şekil 3. Sıfır atık yaklaşımının amaçları 
Çevre kirliliğini önlemek, israfi önlemek, bilinçli bir toplum yaratmak, atık oranını azaltmak, kaynakların verimli kullanılmasını sağlamak. $\left(\ddot{O}_{7}\right)$

Atıkları cam, plastik, kâğıt vb. şeklinde ayırıp geriye sadece yemek atıklarının kalmasıdır. Cam, kâğıt, plastik gibi atıkların ise geri dönüşüme gönderilip tekrar kullanılmasıdır. Doğada binlerce yılda yok olmayan atıkları bilinçli bir şekilde toplamaktır. $\left(\ddot{O}_{15}\right)$

Sıfır atık, daha temiz bir çevre ortamı oluşturmak için. Toprağın değerini kaybetmemesi için. Daha verimli bir toprak elde etmek, bırakabilmek için. Atıkların çevreyi kirletmemesi sağlanmalıdır. Her bir atığın çevreye kazandırılması, doğaya kazandırılması geri dönüşüm yoluyla tekrar kullanılabilecek hale getirilmesi sağlanmalıdır. $\left(\ddot{O}_{17}\right)$

Atıkların karışık bir şeklide birikmesini önlemek. Tüm atıkların ayrı ayrı toplanmasına olanak sağlar. Ayrı ayrı toplanan bu atıklar uygun şekilde ayrıştırılır ve geri dönüştürülür. Bu sayede çevre ve doğa korunmuş olur. Ekonomiye katkı sağlar. $\left(\ddot{O}_{19}\right)$

Fen Bilgisi öğretmen adaylarının sıfır atık yaklaşımına uygun olacak şekilde tasarladıkları bez çantalar için yaptıkları çizimler analiz edilerek Tablo 1'de verilmiştir.

Tablo 1 incelendiğinde öğretmen adaylarının geri dönüşüm, atık ayırma, yeniden kullanım ve etkileri olmak üzere 4 kategoride çizimler yaptıkları görülmektedir. Çizimler geri dönüşüm kategorisinde geri dönüşüm işareti (f:12), atık ayırma kategorisinde bireyin rolü ve önemi (f:4), etkileri kategorisinde temiz doğa (f:12) kodlarında yoğunlaşmaktadır. Buna ilaveten 2 öğretmen adayının yeniden kullanım kategorisinde çizimler yaptığı belirlenmiştir. Ayrıca, 3 öğretmen adayının tüm atık türlerinin aynı geri dönüşüm kutusuna atılması gerektiğini vurgulayan çizimler yapmaları geri dönüşümün mantığına uymayan dikkat çekici bir sonuçtur. 
Tablo 1. Sıfır Atık Yaklaşımına Uygun Bez Çanta Tasarımı

\begin{tabular}{|c|c|c|c|}
\hline Kategori & \multicolumn{2}{|l|}{ Kod } & $\mathbf{f}$ \\
\hline Geri dönüşüm & \multirow{2}{*}{\multicolumn{2}{|c|}{$\begin{array}{l}\text { Geri dönüşüm işareti } \\
\text { Geri dönüşüme uğrayan atık örnekleri }\end{array}$}} & 12 \\
\hline & & & 2 \\
\hline & \multicolumn{2}{|c|}{ Atıkların yeni ürünlere (kâğıt, cam, metal) dönüştürülmesi } & 1 \\
\hline & \multicolumn{2}{|c|}{ Organik atıkların gübre olarak kullanılması } & 1 \\
\hline & \multicolumn{2}{|c|}{ Doğada kendiliğinden çözünebilen plastik ürünler (pet şişe ve poşet) } & 1 \\
\hline & \multicolumn{2}{|l|}{ Geri dönüşüm tesisi } & 1 \\
\hline & \multicolumn{2}{|c|}{ Geri dönüştürülemeyen atıkların çöp olması } & 1 \\
\hline & \multirow{7}{*}{ Geri dönüşüm kutusu } & Plastik & 4 \\
\hline & & Kâğıt & 4 \\
\hline & & Cam & 2 \\
\hline & & Atık pil & 1 \\
\hline & & Metal & 1 \\
\hline & & Organik & 1 \\
\hline & & Tüm atıklar & 3 \\
\hline \multirow[t]{3}{*}{ Atık ayırma } & \multirow{3}{*}{\multicolumn{2}{|c|}{$\begin{array}{l}\text { Bireyin rolü ve önemi } \\
\text { Kâğıt ve cam atıkları ayırma } \\
\text { Tüm atık türlerini ayırma }\end{array}$}} & 4 \\
\hline & & & 1 \\
\hline & & & 1 \\
\hline \multicolumn{3}{|l|}{ Yeniden kullanım } & 2 \\
\hline \multirow[t]{6}{*}{ Etkileri } & \multirow{2}{*}{\multicolumn{2}{|c|}{$\begin{array}{l}\text { Temiz doğa } \\
\text { Mutlu insan }\end{array}$}} & 12 \\
\hline & & & 5 \\
\hline & \multicolumn{2}{|c|}{ Kâğıt geri dönüşümü ile ham madde kaynaklarının korunması } & 4 \\
\hline & \multicolumn{2}{|l|}{ Mutlu doğa } & 1 \\
\hline & \multicolumn{2}{|l|}{ Küresel 1sınma } & 1 \\
\hline & \multicolumn{2}{|c|}{ Yapılmadığında oluşabilecekler } & 1 \\
\hline
\end{tabular}

Öğretmen adaylarının sıfır atık yaklaşımına uygun olacak şekilde tasarladıkları bez çantalardan bazı örnekler öğrenci numaraları ile birlikte Şekil 4’te verilmiştir. 


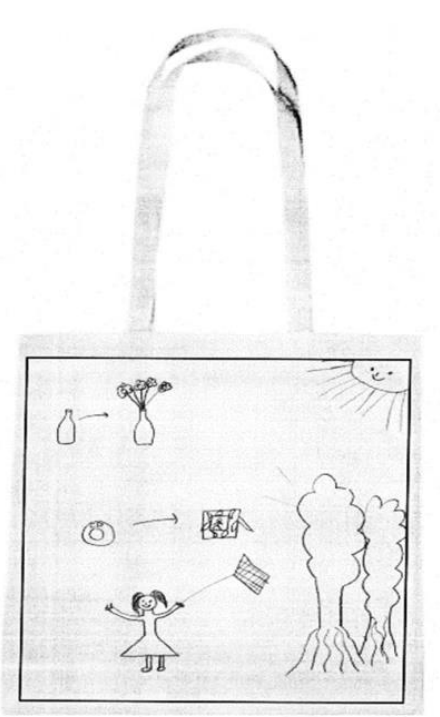

$\ddot{O}_{1}$

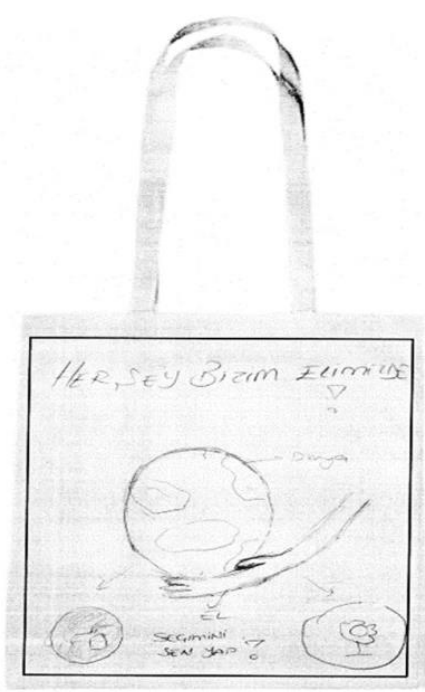

$\ddot{\mathbf{O}}_{7}$

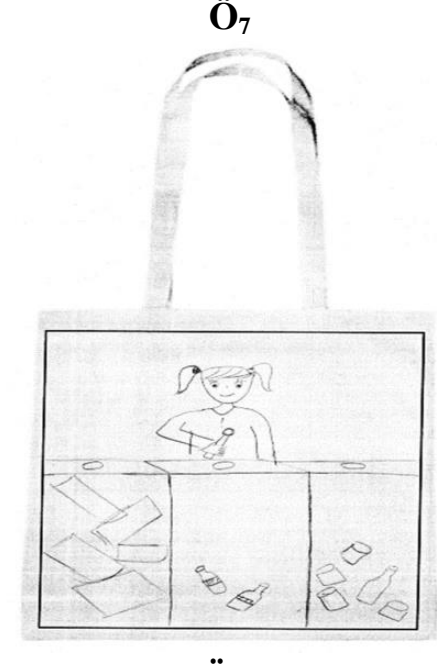

$\ddot{O}_{23}$

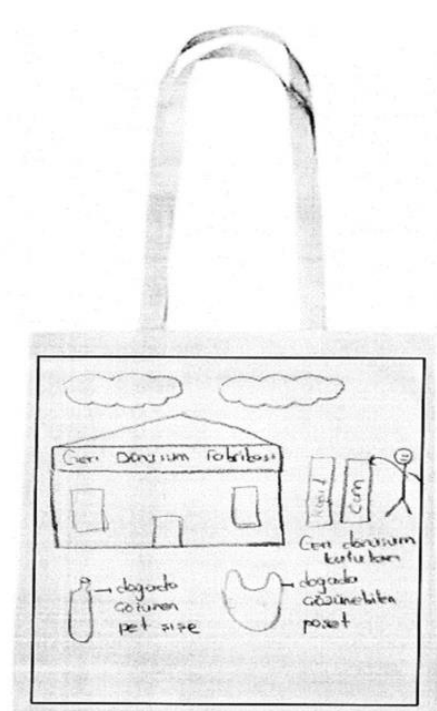

$\ddot{\mathrm{O}}_{2}$

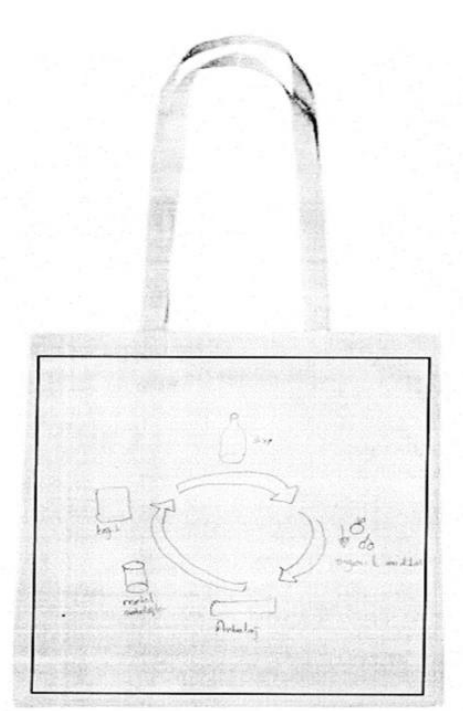

$\ddot{O}_{10}$

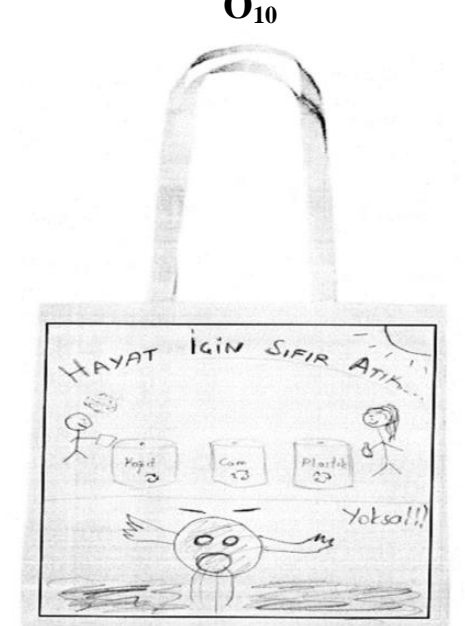

$\ddot{\mathrm{O}}_{24}$

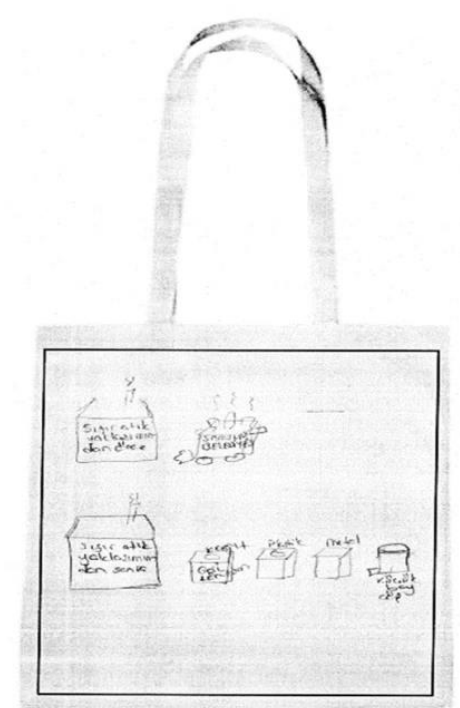

$\ddot{O}_{6}$

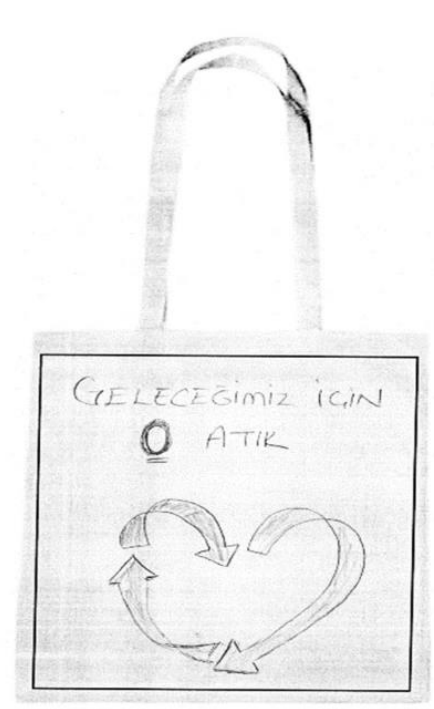

$\ddot{O}_{18}$

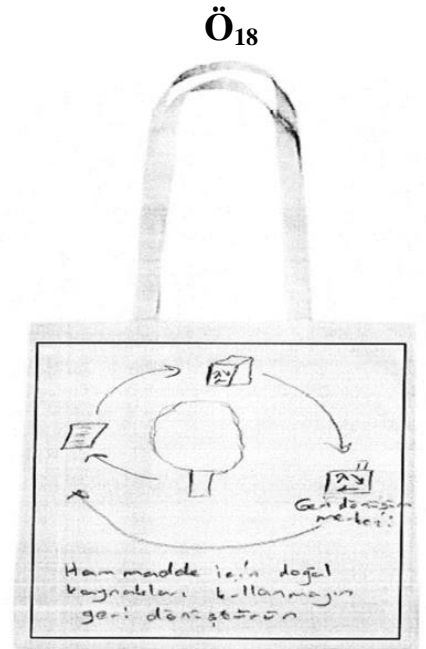

$\ddot{\mathbf{O}}_{27}$

Şekil 4. Öğretmen adaylarının tasarladıkları bez çantalardan bazı örnekler 
Şekil 4 incelendiğinde bazı öğretmen adaylarının yaptıkları bez çanta tasarımlarının üzerine çeşitli sloganlar yazdıkları görülmektedir. Bu sloganlar aşağıda verilmiştir.

“Her şey bizim elimizde! Seçimini sen yap!" $\left(\ddot{O}_{7}\right)$ ve "Var mısın yok musun" $\left(\ddot{O}_{11}\right)$ sloganları ile öğretmen adayları sıfır atık yaklaşımında bireysel tercihlerin etkililiği ile bu hususta bireyin görev ve sorumluluklarını yerine getirmesinin gerekliliğini vurgulamışlardır.

Bazı öğretmen adayları "Temiz ve sosyal çevre sıfır atık" $\left(\ddot{O}_{12}\right)$, "No atık yes temiz hava" (Ö$\left.{ }_{13}\right)$, "0 atıkla doğa daha temiz" (Ö $\left.{ }_{22}\right)$, "Sifır atık temiz çevre" $\left(\ddot{O}_{29}\right)$ sloganları ile sıfir atık yaklaşımının temizlik; "Geri dönüşüme atalım. Çöplerden ayıralım. Sıfır atık ile tasarruf sağlayalım...” $\left(\ddot{O}_{25}\right)$ sloganı ile tasarruf üzerindeki etkilerini ifade etmişlerdir.

Bazıları da "Sıfır atık sağlıklı yaşam" (Ö $\left.{ }_{14}\right)$, "Yaşanabilir bir çevre için sıfır atık" (Ö "Sıfır atık ile yaşanabilir bir çevre" $\left(\mathrm{O}_{21}\right)$, "Güzel bir yaşam için kesin çözüm” $\left(\ddot{O}_{20}\right)$, "Güzel dünya için sıfır atıkla ilk adımı atın" (Ö$\left.{ }_{16}\right)$, "Atıkları topla geri dönüşüme yolla. Daha güzel bir çevre için atıkları geri dönüşüme verin.” (Ö $\left.{ }_{17}\right)$ sloganlarıyla sağlıklı ve güzel bir yaşam ile yaşanabilir ortamlar oluşturmada sıfır atık yaklaşımının etkili olduğunu belirtmişlerdir.

Bir öğretmen adayı "Geleceğimiz için 0 atık" $\left(\ddot{O}_{18}\right)$ sloganı ile sıfır atık yaklaşımının gelecek için önemine, başka bir öğretmen adayı ise "Hayat için sıfır atık... Yoksa!!!" (Ö $\left.{ }_{24}\right)$ sloganı ile sıfır atık yaklaşımına uygun olmayan davranışların doğurabileceği tehlikeli sonuçlara dikkat çekmiştir.

\section{Tartışma, Sonuç ve Öneriler}

Araştırma sonucunda öğretmen adaylarının sıfır atık yaklaşımına yönelik farkındalıklarının yeterli olmadığı, verdikleri cevaplarda ve yaptıkları çizimlerde sıfır atık yaklaşımını daha çok atık yönetimi ve geri dönüşüm açısından ele aldıkları, yeniden kullanım kavramına fazla değinmedikleri anlaşılmıştır.

Öğretmen adayları sıfır atık kavramını atık yönetimi ve geri kazanım, tasarruf ve çevresel etkileri açısından ele alarak tanımlamışlardır. Tanımlarda geçen geri dönüşüme uğrayabilecek atık madde türlerini öğretmen adaylarının çoğu belirtmezken 7 öğretmen adayı gıda atıkları, ambalaj, şişe, kâğıt, karton, cam, plastik, organik atık, pil, metal olmak üzere sınırlandırarak ifade etmişlerdir. Benzer şekilde alan yazında da geri dönüşüme uğrayabilecek atık madde türlerinin sınırlandırılarak ifade edildiği ortaya koyulmuştur (Can-Yaşar vd. 2012). Öyle ki, geri dönüşüme uğrayabilecek atık madde türlerini Fen Bilgisi öğretmen adaylarının kâğıt, plastik, cam, katı atık, pil, PET, karton, pet şişe (Harman ve Çelikler, 2016), biyoloji bölümündeki öğrenciler (Soran vd. 2000) ile ortaöğretim ve üniversite öğrencilerinin plastik, depozitolu kutular ve kola şişeleri (Yılmaz vd. 2002), biyoloji bölümündeki öğrencilerin kâğıt, cam, metal ve organik madde (Soran vd. 2000), fizik, kimya ve biyoloji öğretmen adaylarının kâğıt, plastik ve cam (Demircioğlu, Demircioğlu ve Yadigaroğlu, 2015) olarak sınırlandırmış oldukları saptanmıştır.

Bazı öğretmen adayları ise gıdaları ve organik atıkları geri dönüşümü mümkün olan atık kapsamında değerlendirirken, bazıları gıdaların ve organik atıkların geri dönüşümünün olmayacağını ifade etmiştir. Öğretmen adaylarının geri dönüşümü mümkün olduğu halde 
gıdaların ve organik atıkların geri dönüşümünün mümkün olmadığını düşünmeleri dikkat çekicidir.

Sıfır atık yaklaşımının uygulanmasının gerekli olduğunu ifade eden $27(\% 93,1)$ öğretmen adayı bu gerekliliği atık yönetimi ve geri kazanım, çevresel etkiler, tasarruf ve ekonomi açısından ele alırken, 2 (\% 6,9) öğretmen adayı karasız olduklarını ifade etmişlerdir. Alan yazında da Fen Bilgisi öğretmen adaylarının büyük çoğunluğunun sıfır atık yaklaşımının önemli bir bileşeni olan geri dönüşümün atıkların çevreye vereceği zararı ve çevre kirliliğini önlemek, atık malzemeleri tekrar kullanıma kazandırmak, ham madde kaynaklarının tükenmesini önlemek için gerekli olduğunu ifade ettikleri ortaya koyulmuştur (Harman ve Çelikler, 2016).

Sıfır atık yaklaşımının amaçlarını öğretmen adayları atık yönetimi ve geri kazanım, çevresel etkiler, tasarruf açısından değerlendirerek atık miktarını azaltmak, atıkları geri dönüşüm ile kazanmak, yaşanabilir bir çevre oluşturmak, insan sağlığını korumak, ham madde kaynaklarını verimli kullanmak, israfı önlemek, ekonomiye katkı sağlamak ve toplumu bilinçlendirmek olarak ifade etmişlerdir. Benzer şekilde alan yazında da Fen Bilgisi öğretmen adaylarının önemli bir bölümünün atık maddelerin çevreye zarar vermesini ve çevre kirliliğini önlemek, enerji tasarrufu ve ekonomi üzerinde yoğunlaşarak atık maddelerin tekrar kullanılmasını sağlamak ve ham madde kaynaklarının tükenmesini önlemek amacıyla sıfır atık yaklaşımının önemli bir bileşeni olan geri dönüşümün yapıldığını ifade ettikleri ortaya koyulmuştur (Harman ve Çelikler, 2016).

Araştırmadan elde edilen sonuçlar temelinde öğretmen adayları ve öğrenciler için aşağıdaki öneriler sunulmuştur.

Öğretmen adaylarını güdülemek amacı ile üniversiteler ve TEMA, ÇEVKO gibi kuruluşlar arasında işbirliği yapılarak ödüllü sıfır atık projeleri hazırlanabilir.

Geleceğin öğrencilerini yetiştirecek olan öğretmen adaylarını kendi atıklarını ayrıştırarak doğru geri dönüşüm kutularına atmaları konusunda teşvik etmek için ücretsiz yemek, ücretsiz ulaşım vb. imkânlar sağlanabilir.

Öğretmen adaylarına sıfır atık ile ilgili posterler, gazeteler hazırlatılabilir ve gerekli izinler alınarak staj için gittikleri okullarda öğrencileri bilgilendirme amaçlı kullanmaları sağlanabilir.

Okul Deneyimi veya Öğretmenlik Uygulaması dersleri kapsamında okullara giden öğretmen adaylarından yere bırakılan bir pet şişe, teneke kutu, pil vb. atıklara yönelik öğrencilerin tepkilerinin ne olacağını, atıkları doğru geri dönüşüm kutularına atıp atmayacaklarını saptamak için sosyal deneyler yapmaları ve doğru yere atan öğrencileri ödüllendirmeleri istenebilir.

Kimyada Özel Konular, Çevre Eğitimi, Çevre Bilimi vb. derslerin kapsamında kısıtlı bir süre içinde bilgi vermek yerine lisans ve lisansüstü eğitime tamamen sıfır atık yaklaşımına yönelik konuları içeren dersler eklenebilir. 


\section{Kaynakça}

Akbayrak, N. ve Kuru-Turaşlı, N. (2017). Oyun temelli çevre etkinliklerinin okul öncesi çocukların çevresel farkındalıklarına etkisinin incelenmesi. Erken Çocukluk Çalışmaları Dergisi, 1(2), 239258. DOI: $10.24130 /$ eccd-jecs. 196720171240

Aksan, Z. ve Çelikler, D. (2018). Models by science teacher candidates for the teaching the reutilization of wastes. Kastamonu Education Journal, 26(5), 1461-1467. DOI:10.24106/kefdergi.2021

Aksan, Z., Harman, G. ve Çelikler, D. (2015). Evaluation through the use of drawings of the knowledge of science teacher candidates in Turkey regarding the recycling of waste batteries. International Journal of Sustainable and Green Energy, 4(1-2), 1-5. DOI: 10.11648/j.jirse.s.2015040102.11

Aktepe, S. ve Girgin, S. (2009). Comparison of eco-schools and other primary schools in terms of environmental education. Elementary Education Online, 8(2), 401-414.

Atabek-Yiğit, E. ve Ceylan, Ö. (2015). Utilization of flow maps in the determination of cognitive structure of secondary school students regarding the concept of recycling and reuse. International Online Journal of Educational Sciences, 7(2), 155-166. DOI: http://dx.doi.org/10.15345/iojes.2015.02.012

Can-Yaşar, M., İnal, G., Kaya, Ü. Ü. ve Uyanık, Ö. (2012). Çocuk gözüyle tabiat anaya geri dönüş. Ĕgitim ve Öğretim Araştırmaları Dergisi, 1(2), 30-40.

Choiriyah, I. O. (2017). The implementation of zero waste program to support environmental security. Advances in Social Science, Education and Humanities Research, 125, 333-337. DOI: https://doi.org/10.2991/icigr-17.2018.80

Connent, P. (2007). Zero waste: A key move towards a sustainable society. [Available online at: https://www.researchgate.net/publication/228871831_Zero_Waste_A_Key_Move_towards_a_Sust ainable_Society], Retrieved on May 7, 2019.

Cresswell, J. W. (2017). Karma yöntem araştırmalarına giriş (1. Basım). (Çev. ed. M. Sözbilir). Ankara: Pegem Akademi Yayıncılık.

Çelikler, D. \& Harman, G. (2015). The effect of the SCAMPER technique in raising awareness regarding the collection and utilization of solid waste. Journal of Education and Practice, 6(10), 149-159.

Çimen, O. ve Yılmaz, M. (2012). İlköğretim öğrencilerinin geri dönüşümle ilgili bilgileri ve geri dönüşüm davranışları. Uludağ Üniversitesi Eğitim Fakültesi Dergisi, 25(1), 63-74.

Demircioğlu, G., Demircioğlu, H. ve Yadigaroğlu, M. (2015). Fizik, kimya ve biyoloji öğretmen adaylarının çevre bilinç düzeylerinin değerlendirilmesi. Adlyaman Üniversitesi Sosyal Bilimler Enstitüsü Dergisi, 8(19), 167-193. DOI: http://dx.doi.org/10.14520/adyusbd.41708

Develi, E., Gürsoy, H. H., Özçelik, E., Emik, H., Yavuz, G., Aydede-Yalçın, M. N., vd. (2017). Ortaokul öğrencilerinin ambalaj atıklarının geri dönüşümüne yönelik görüşlerinin incelenmesi: (Niğde ili örneği). Uluslararası Türk Kültür Coğrafyasında Sosyal Bilimler Dergisi, 2(1), 86-100.

Ebrahimi, K. (2015). "Zero-waste planning at higher education institutions: A Case Study of Western Kentucky University". The Faculty of the Department of Geography and Geology Western Kentucky University, Bowling Green, Kentucky. Masters Theses \& Specialist Projects. Paper 1514. [Available online at: http://digitalcommons.wku.edu/theses/1514], Retrieved on May 18, 2019.

Elgizawy, S. M., El-Haggar, S. M. \& Nassar, K. (2016). Approaching Sustainability of Construction and Demolition Waste Using Zero Waste Concept. Low Carbon Economy, 7, 1-11. [Available online at: http://dx.doi.org/10.4236/lce.2016.71001], Retrieved on May 18, 2019.

Ertürk, R. (2017). Environmental problems of the primary school students and perceptions for environmental education. İönü University Journal of the Faculty of Education, 18(3), 12-24. DOI: $10.17679 /$ inuefd. 354142

French, L., Hamman, L., Katz, S. \& Kozaki, Y. (2010). Zero waste strategies for gills onions sustainable innovation and waste management. A 2010 group project proposal, [Available online at: 
https://www.bren.ucsb.edu/research/documents/onions_proposal.pdf], Retrieved on April 25, 2019.

Gönüllü, M. T., Doğan, S. \& Çelik, Z. (2015). İlköğretim öğrencilerinin çevre için zararlı ambalaj atıkları hakkında farkındalı̆̆ı (İstanbul örneği). Millî Ĕgitim Dergisi, 205, 44-63.

Grodzinska-Jurczak, M., Bartosiewicz, A., Twardowska, A. \& Ballantyne, R. (2003). Evaluating the impact of a school waste education programme upon students', parents' and teachers' environmental knowledge, attitudes and behaviour. International Research in Geographical and Environmental Education, 12(2), 106-122. DOI: https://doi.org/10.1080/10382040308667521

Gülhan, F. ve Yurdatapan, M. (2014). 5E modeline uygun araştırma sorgulamaya dayalı etkinliklerin 5. sınıf öğrencilerinin çevre ile ilgili tutum ve davranışlarına etkisi. Mustafa Kemal Üniversitesi Sosyal Bilimler Enstitüsü Dergisi, 11(27), 237-258.

Gürer, A. ve Sakız, G. (2018). Yetişkinlerin küresel ısınma ile ilgili bilgi düzeyleri ve geri dönüşüm farkındalıkları. Insan ve Toplum Bilimleri Araștırmaları Dergisi, 7(2), 1364-1391.

Harman, G. (2017). Fen bilgisi öğretmen adaylarının sürdürülebilirlik kavramı hakkındaki farkındalıkları: Benim okulum. Necatibey Eğitim Fakültesi Elektronik Fen ve Matematik Eğitimi Dergisi (EFMED), 11(2), 243-262.

Harman, G. ve Çelikler, D. (2015). The development of conceptual models for teaching waste material recovery to middle school students. Journal of Materials Education, 37(5-6), 227-238.

Harman, G., Aksan, Z. \& Çelikler, D. (2015). Mental models which influence the attitudes of science students towards recycling. International Journal of Sustainable and Green Energy, 4(1-2), 6-11. DOI: $10.11648 / j$.jijse.s.2015040102.12

Harman, G. ve Çelikler, D. (2016). Fen bilgisi öğretmen adaylarının geri dönüşüm kavramı hakkındaki farkındalıkları. Abant İzzet Baysal Üniversitesi Sosyal Bilimler Enstitüsü Dergisi, 16(1), 331-353.

Harman, G. ve Çelikler, D. (2018). The opinions of elementary science teacher candidates regarding the collection, separation and recycling of solid wastes. Kastamonu Education Journal, 26(3), 813822. DOI:10.24106/ kefdergi.413329

Lehmann, S. (2011). Resource recovery and materials flow in the city: Zero waste and sustainable consumption as paradigms in urban development. Sustainable Development Law \& Policy, 11(1), 28-68.

Miles, M. B. \& Huberman, A. M. (1994). Qualitative data analysis. Thousand Oaks, CA: Sage Publication.

Millî Eğitim Bakanlığı [MEB] (2018). Fen Bilimleri Dersi Öğretim Programı (İlkokul ve ortaokul 3, 4, 5 , 6, 7 ve 8 . siniflar). Ankara.

Monok, B., Stoykova, I., Bendere, R., Tömöri, B. \& Popelkova, J. (2006). Zero waste as best environmental practice for waste management in CEE countries. M. Havel (Eds.), International POPs Elimination Project, Czech Republic.

Nayak, A. (2016). Trash free living-sustainable future. International Journal of Current Research in Biosciences and Plant Biology, 3(2), 69-76. DOI: http://dx.doi.org/10.20546/ijcrbp.2016.302.009

Nizar, M., Munir, E., Munawar, E. \& Irvan, D. (2018). Implementation of zero waste concept in waste management of Banda Aceh city. International Conference on Science and Technology, 1-12. DOI:10.1088/1742-6596/1116/5/052045

Oktaviani, S. \& Supriatna, N. (2018). Social studies learning through zero waste lifestly journal programs to develop student ecoliteracy. The 3rd International Seminar on Social Studies and History Education, 542-548.

Onur, A., Çağlar, A. ve Salman, M. (2016). 5 yaş okulöncesi çocuklarda atık kâğıtların değerlendirilmesi ve çevre bilincinin kazandırılması. Kastamonu Ĕgitim Dergisi, 24(5), 2457-2468.

Özbakır-Umut, M., Topuz, Y. V. \& Nurtanış-Velioğlu, M. (2015). Çöpten geri dönüşüme giden yolda sürdürülebilir tüketiciler. Celal Bayar Üniversitesi Sosyal Bilimler Dergisi, 13(2), 263-288. DOI: $10.18026 /$ cbusos. 68623 
Paghasian, M. C. (2017). Awareness and practices on solid waste management among college students in Mindanao State University Maigo school of arts and trades. Advances in Social Science, Education and Humanities Research, 128, 5-12.

Pietzsch, N., Duarte-Ribeiro, J. L. \& Medeiros, J. F. (2017). Benefits, challenges and critical factors of success for zero waste: A systematic literature review. Waste Management, 67, 324-353. DOI: 10.1016/j.wasman.2017.05.004

Samiha, B. (2013). The importance of the 3R principle of municipal solid waste management for achieving sustainable development. Mediterranean Journal of Social Sciences, 4(3), 129-135. DOI:10.5901/mjss.2013.v4n3p129

Snow, W. (2002, 17th October). Zero waste - the end of waste? Zero waste Conference, Western Super Mare, England, 1-10.

Song, Q., Li, J. \& Zeng, X. (2015). Minimizing the increasing solid waste through zero waste strategy. Journal of Cleaner Production, 104, 199-210. DOI: http://dx.doi.org/10.1016/j.jclepro.2014.08.027

Soran, H., Morgil, F. İ., Yücel, S., Atav, E. ve Işık, S. (2000). Biyoloji öğrencilerinin çevre konularına olan ilgilerinin araştırılması ve kimya öğrencileri ile karşılaştırılması. Hacettepe Üniversitesi Eğitim Fakültesi Dergisi, 18, 128 -139.

Tariq, M., Naveed, M., Irshad, M. A., Ahsan, H., Zafar, S., Shiraz, H. M. \& Nauman, A. (2017). Assessment of household solid waste generation in rural areas. Journal of Scientific and Engineering Research, 4(11), 27-31.

Tufaner, F. (2019). Geri dönüşebilir atıkların toplanması konusunda yapılan bilgilendirme çalışmalarının toplama verimine katkısının araştırılması. İklim Değişikliği ve Çevre, 4(1) 33-40.

Türkmen, M., Sarıkaya, N. ve Saygıll, M. (2013). Öğrencilerin çevresel duyarlılık düzeylerinin satın alma davranışına etkisi üzerine bir araştırma: Sakarya Üniversitesi örneği. Sosyal ve Beşeri Bilimler Dergisi, 5(2), 238-249.

URL: The 3Rs as the basis for sustainable waste management: Moving towards zero waste (Luis F. Diaz). [Available online at:

http://www.uncrd.or.jp/content/documents/Text\%20for\%20Keynote\%20Address $\% 20$ for $\% 203$ rd\% 20Regional\%203R\%20Forum_Luiz\%20Diaz.pdf], Retrieved on June 15, 2019.

Uz-Zaman, A. \& Lehmann, S. (2013). The zero waste index: A performance measurement tool for waste management systems in a "zero waste city". Journal of Cleaner Production, 50, 123-132. DOI: 10.1016/j.jclepro.2012.11.041

Wegedie, K. T. (2018). Household solid waste generation and management behavior in case of Bahir Dar city, Amhara National Regional State, Ethiopia. Cogent Environmental Science, 4, 1-18. DOI: https://doi.org/10.1080/23311843.2018.1471025

Yakob, N., Esa, N. \& Yunus, H. M. (2012). Exploring secondary school students' belief and attitude about waste management in Northern Peninsular Malaysia. International Journal of Global Education, 1(1), 35-46.

Yalçınkaya, E. (2013). İlköğretim 8. sınıf öğrencilerine göre çevre sorunları: Nitel bir çalışma. Marmara Coğrafya Dergisi, 27, 416-439.

Yardımcı, E. ve Bağcı-Kılıç, G. (2010). Children's views of environment and environmental problems. Elementary Education Online, 9(3), 1122-1136.

Yılmaz, A., Morgil, İ., Aktuğ, P. ve Göbekli, İ. (2002). Ortaöğretim ve üniversite öğrencilerinin çevre, çevre kavramları ve sorunları konusundaki bilgileri ve öneriler. Hacettepe Üniversitesi Eğitim Fakültesi Dergisi, 22, 156-162. 


\section{Extended Abstract}

\section{Introduction}

The zero waste approach includes the 3R rule "Reduction, Reuse and Recycle" which forms the basis of environmental awareness (Song, Li \& Zeng, 2015). Most people have knowledge on reduce, reuse and recycling, but responsibility is fourth element that is key of sustainability. In order to the zero waste approach gain sustainable quality, each person must be involved in the problem (Connent, 2007) and the decision-making process (Tariq, Naveed, Irshad, Ahsan, Zafar, Shiraz \& Nauman, 2017). In this context, all kinds of educational institutions, especially higher education institutions should assume an important leadership role in the environmental protection movement (Ebrahimi, 2015). The preservice teacher who are a part of higher education institutions both at the higher education institutions where they study and at the schools where they will work in the future, together with their students both reach the targets in the curriculum and affect the parents of students through the students and the contribution that they will provide to the recycling of wastes in the social dimension. When this contribution is taken into consideration, it is necessary to reveal whether they have awareness on the zero waste approach. In this study, which was based on this requirement, it was aimed to examine the awareness of preservice science teacher towards zero waste approach.

\section{Method}

The research was conducted using the general screening model in the spring semester of 20182019. The study group consisted of 29 preservice science teachers who were attending at the fourth grade of the Science Education Department of a Faculty of Education at a public university. Awareness form which was prepared by the researchers was used as data collection tool. Preservice teachers were asked to write the definition of zero waste concept, the necessity of applying zero waste approach and the objectives of zero waste approach with three open-ended questions in this form; also, they were asked to design a cloth bag suitable for zero waste approach and to present their designs with drawings. The data obtained were analyzed separately by two researchers. The resulting codes and categories were combined, compared and edited. Tables were created and interpreted using frequency values of the data which was analyzed by content analysis. In addition, raw data, codes and categories were examined by an expert (chemistry educator). Direct citations from preservice science teachers' answers and sample photographs from their drawings were included.

\section{Results and Discussion}

Preservice science teachers defined the concept of zero waste in terms of waste management and recovery, saving and environmental effects. In the definitions, the types of recyclable waste was specified by 7 preservice science teachers. They limited the types of recyclable waste. They expressed these waste as food waste, packaging, bottle, paper, cardboard, plastic, organic waste, battery, glass and metal. Similarly, in the literature, it was shown that the types of recyclable waste materials were limited (Can-Yaşar et al. 2012). So, preservice science teachers expressed paper, plastic, glass, solid waste, batteries, PET, cardboard, pet bottles (Harman \& Çelikler, 2016), students in biology department (Soran et al. 2000) and secondary education students and university students expressed plastic, returnable cans and coke bottles (Y1lmaz et al. 2002), students in biology department expressed paper, glass, metal and organic matter (Soran et al. 
2000) students in physics, chemistry and biology department expressed paper, plastic and glass (Demircioğlu, Demircioğlu \& Yadigaroğlu, 2015) as the types of recyclable waste. Some preservice teachers evaluated foods, organic waste as recyclable waste, while others expressed that foods, organic waste wouldn't be recycled. It is noteworthy that preservice teachers think that it isn't possible to recycle food and organic waste, although it is possible to recycle it.

While $27(93.1 \%)$ preservice teachers stated that it is necessary appliying of the zero waste approach, this requirement was handled in terms of waste management and recovery, environmental impacts, savings and economy, while $2(6.9 \%)$ teachers stated that they were undecided. In the literature, it was revealed that the majority of preservice science teachers stated that recycling, which is an important component of zero waste approach, is necessary to prevent environmental damage and pollution of wastes, recycling waste materials and preventing depletion of raw material resources (Harman \& Çelikler, 2016). The preservice science teachers evaluated the aim of the zero waste approach in terms of waste management and recovery, environmental impacts, savings. They expressed the aim of the zero waste approach as reducing the amount of waste, gaining waste with recycling, creating a livable environment, protecting human health, using raw material resources efficiently, preventing waste, contributing to the economy and raising awareness of society. Similarly, in the literature, a significant part of preservice science teachers expressed the aim of recycling as preventing damage of the waste materials to the environment and environmental pollution; ensuring the reuse of waste materials and preventing depletion of raw material resources (Harman \& Çelikler, 2016).

When the results obtained from the research were evaluated, it was understood that preservice science teachers' awareness on zero waste approach wasn't sufficient and they considered the zero waste approach mostly in terms of waste management and recycling; they didn't mention the concept of reuse in their answers and drawings. 